\title{
PLUGGING METER AND CONTINUOUS OXYGEN METER
}

by

B. Minushkin

\section{Prepared for Panel Discussion "ON-LINE MONITORING TECHNIQUES"}

Sodium Components Development Program Information Meeting Hollywood, California

\section{April 14, 1964} Performed under Contract AT (30-1)-2877 for the United States Atomic Energy Commission

This report was prepared as an account of Government sponsored work. Neither the Unjted States, nor the Commission, nor any person acting on behalf of the Commission

A Makes any warranty or representation, expressed or implied, with respect to the accuA Makes any warranty or representatton, expressed or lmpled, wh respect to the necuracy, completeness, or usefulness of the information, apparatus, method, or process disclosed in this report may not infringe of any informatlo, apparatus,

privately owned rights, or
B Assumes any liabllities with respect to the use of, or for damages resulting from the B Assumes any liablittes with respect to the use of, of for damages resul

of any information, apparatus, method, or process disclosed in this report.
As used in the above, "person acting on behalf of the Commission" includes any em-

As used in the above, "person acting on behalf of the Commiston, or employee of auch contractor, to the extent that ployee or contractor of the Commission, or employee of such contractor, to the extent thace such employee or contractor of the Commission, or employee of such contractor proparos, with the Commission, or his employment with such contractor. 


\section{DISCLAIMER}

Portions of this document may be illegible in electronic image products. Images are produced from the best available original document. 


\section{PLUGGING MFTER AND CONTINUOUS OXYGEN METER \\ by \\ B. Minushkin \\ Prepared for Panel Discussion "ON-LINE MONITORING TECHNIQUES"}

Sodium Components Development Program Information Meeting Hollywood, California

April 14, 1964

Development Work on "Continuous Electrochemical Oxygen Meter" Performed under Contract AT(30-1)-2877 for the United States Atomic Energy Commission

\section{UNITED NUCLEAR CORPORATION}

Development Division

White Plains, New York 


\section{INTRODUCTION}

This paper is concerned with two types of "on-line" impurity meters: the Plugging Meter and the Electrochemical Oxygen Meter. The plugging meter is well known and has been used extensively on all types of sodium systems. I will briefly mention its major drawbacks and describe a recent development in its design and usage. The electrochemical monitor is a relatively new device not yet out of the laboratory development stage. I will discuss its characteristics as a continuous "on-line" oxygen meter and describe a typical sensor design.

\section{THE PLUGGING METER}

The plugging meter has been, and continues to be, an extremely valuable "on-line" impurity meter. It is particularly suited to monitoring initial cleanup operations and to indicate changes which might lead to plugging of coolant passages, or accelerated corrosion.

It suffers from three inherent drawbacks: 
1. It cannot, in general, differentiate between impurities. This is important if the concern is with corrosion rather than with system plugging.

2. It cannot be used in hot trapped systems where the impurity saturation temperature is below about $250^{\circ} \mathrm{F}\left(120^{\circ} \mathrm{C}\right)$.

3. The plugging temperature is generally different from true saturation temperature. It appears to be influenced by meter design and geometry, operating variables, and the precipitation characteristics of the specific impurities.

A recent development related to design and operation of plugging meters is worthy of mention, although I am sure many of you are aware of it. The French have reported the development of a fully automatic plugging meter which gives a continuous indication of incipient plugging temperature. ${ }^{1}$ Cooling is adjusted to the flow of sodium so as to maintain the flow at a constant value corresponding to incipient plugging of the orifice. The flowmeter output controls the cooling of the sodium. A rise in impurity content would tend to plug the orifice and decrease flow. The controls act to increase the temperature at the orifice and maintain constant flow. Thus, the measured orifice temperature shows continuously the plugging temperature of the sodium. This, if successful, would seem to remove one of the disadvantages of the plugging meter, i.e., the fact that it is not continuously indicating and requires a significant time to make a plugging temperature determination. 


\section{THE ELECTROCHEMICAL OXYGEN METER}

The electrochemical oxygen meter, in principle, is an ideal "on-line" oxygen meter. ${ }^{2}$ It is specific for oxygen, potentially independent of other methods for calibration, sensitive to small changes in oxygen concentration, and capable of rapid and continuous indications of changes in oxygen content. It is, however, tied for the present to the use of a relatively fragile ceramic tube.

The sensing element of the electrochemical oxygen meter, shown schematically in Fig. 1, is a galvanic cell formed by a closed-end ceramic tube which dips into the sodium stream. The ceramic is a solid electrolyte which, under proper conditions, conducts electricity at elevated temperatures solely by the movement of oxygen ions (hence other impurities cannot interfere). The inside of the cell at the closed end contains a reference electrode which provides electronic contact with the inner ceramic surface and a fixed oxygen concentration. The sodium provides electronic contact with the outer ceramic surface and an unknown but lower oxygen concentration. An emf develops across the cell wall due to the difference in oxygen activity at its two faces. Under the proper conditions, the cell emf is proportional to the logarithm of the oxygen concentration in the sodium, and hence can be used as a sensitive measure of that concentration. The cell voltage is approximately one volt. A twofold change in oxygen content, i.e., 10 to $20 \mathrm{ppm}, 100$ to $200 \mathrm{ppm}$, etc., changes the cell voltage by about $17 \mathrm{mv}$. A $10 \%$ change in oxygen concentration produces a $2.5 \mathrm{mv}$ change in cell voltage. 


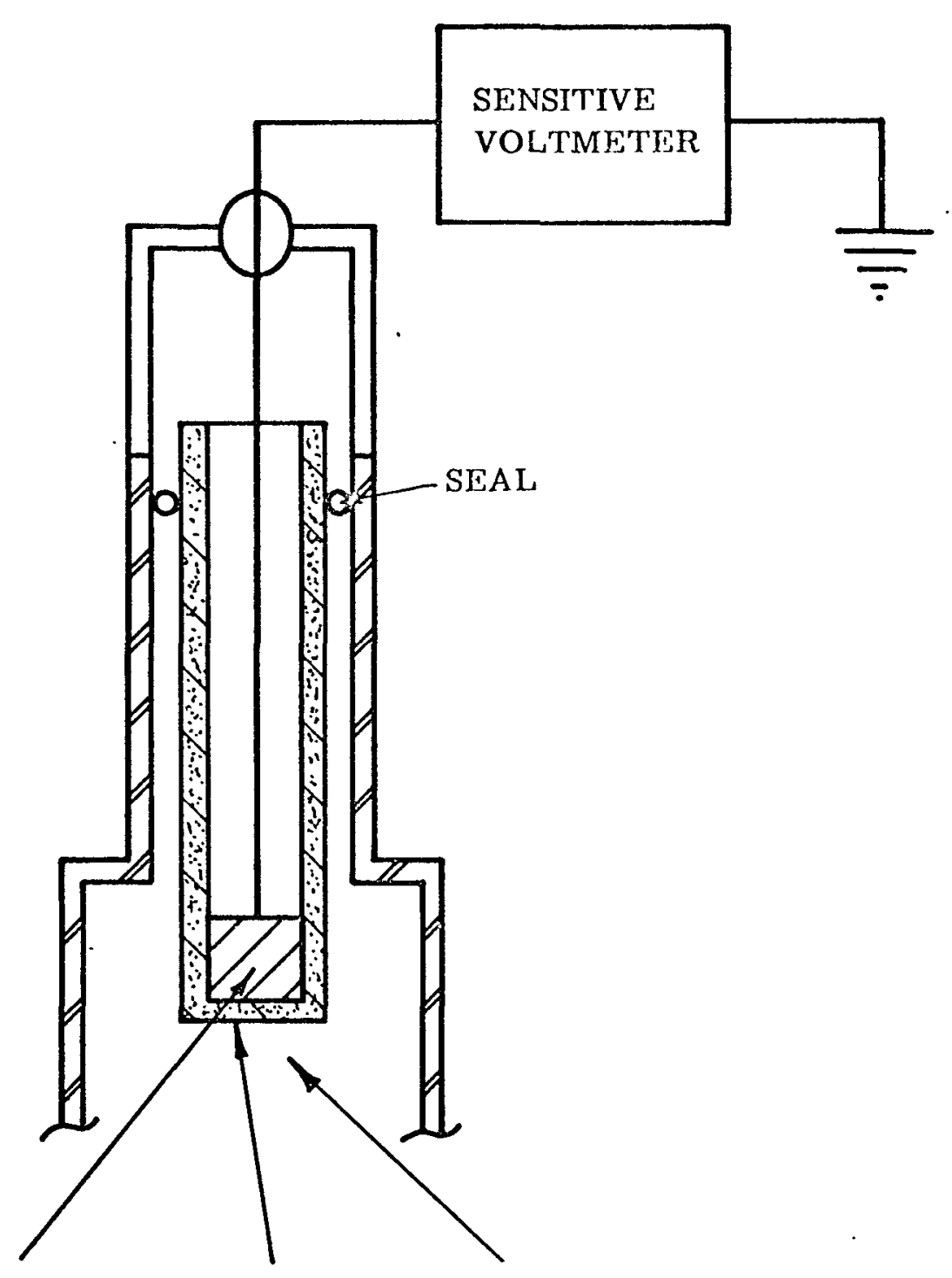

REFERTNCE ELECTRODE ELLCTR̈OLYTE SYSTFM SO DIUM

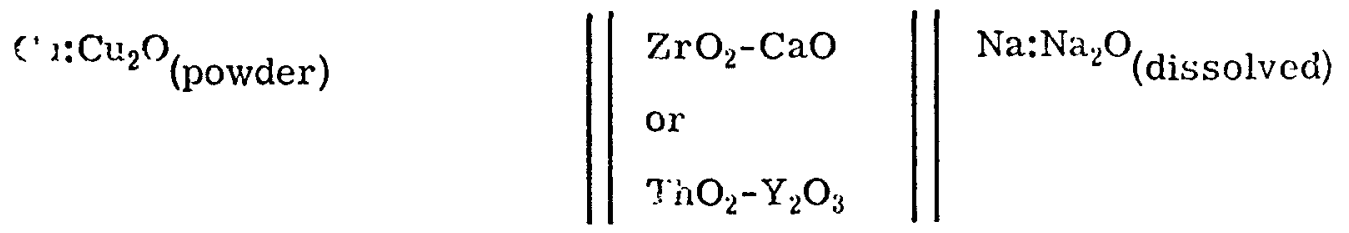

FIG. 1 - SCHEMATIC OF ELECTROCHEMICAL OXYGEN METER 
The feasibility of the electrochemical oxygen meter has been established by extensive tests in cold-trapped thermal convection loops. ${ }^{2}$ Meters were built which generated voltages of about the correct values. The voltages changed with apparent changes in oxygen content of the sodium. This is shown in Fig. 2. This response is typical of hundreds of similar tests. Factors such as electrolyte material, reference electrode, methods of fabrication, and operating conditions were varied. ${ }^{2}$

Meters using $\mathrm{ThO}_{2}-\mathrm{Y}_{2} \mathrm{O}_{3}$ electrolyte and $\mathrm{Cu}: \mathrm{Cu}_{2} \mathrm{O}$ powder reference electrode have been most successful. A number of these meters have operated satisfactorily for periods of over one to three months. During this period of operation the meter voltage has been stable. Its response to changes in cold trap temperature (i.e., oxygen content) has been reproducible and in reasonable agreement with theory. This is illustrated in Fig. 3.

Prior to the period shown on Fig. 3, the same meter had been used for a series of tests which included:

1. Additions of carbon to the sodium

2. Additions of hydrogen to the sodium

3. Removal of the meter from the loop, and subsequent replacement after exposure to air

4. Purging of argon or hydrogen gas through the cathode

5. Shorting the meter.

Meter voltage and te...peraturc, and cold trap temperature during these tests are shown in Fig. 4. Some of these tests disturbed the meter, but 


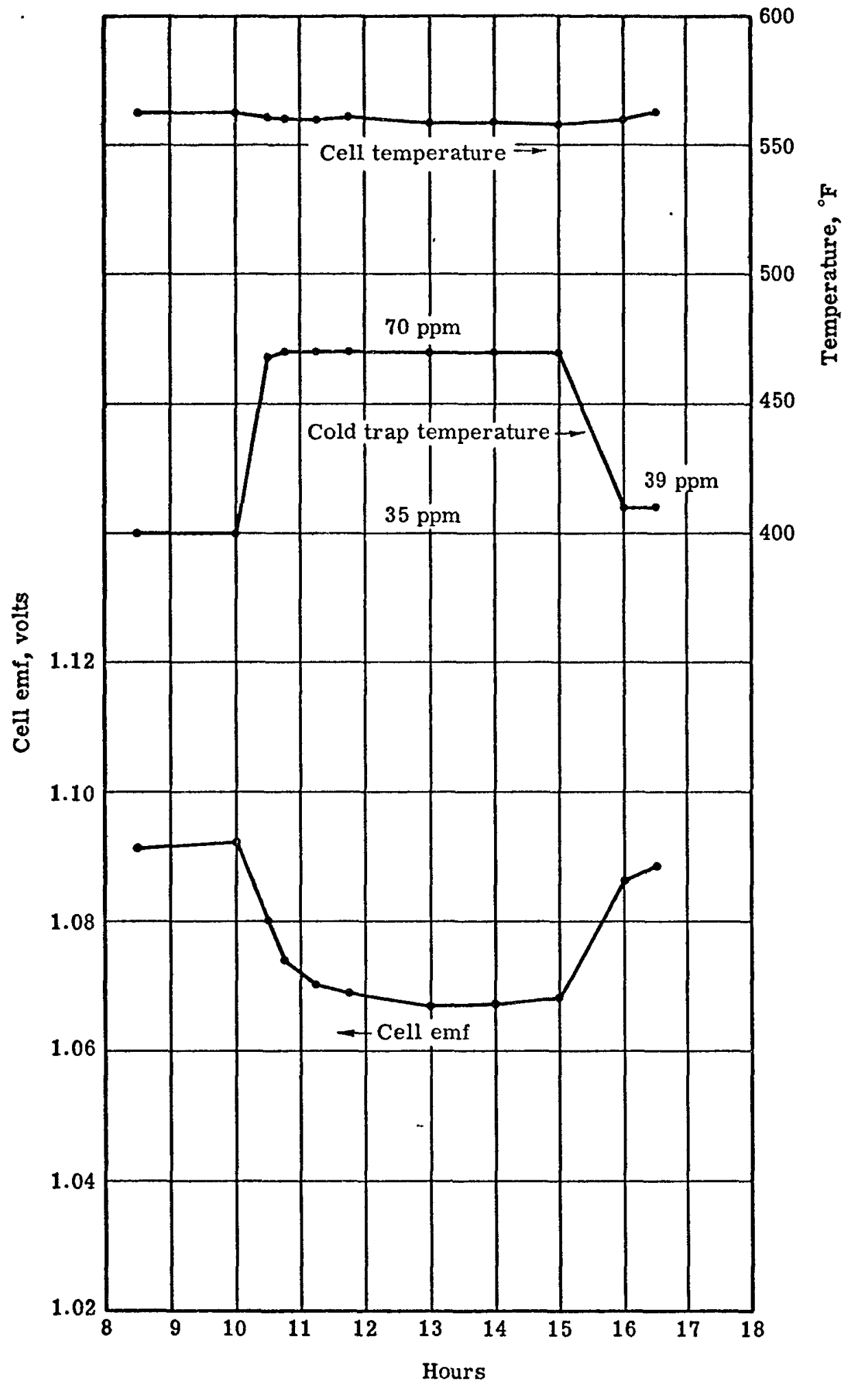

FIG. 2 - METER RESPONSE TO CHANGE IN COLD TRAP TEMPERATURE 


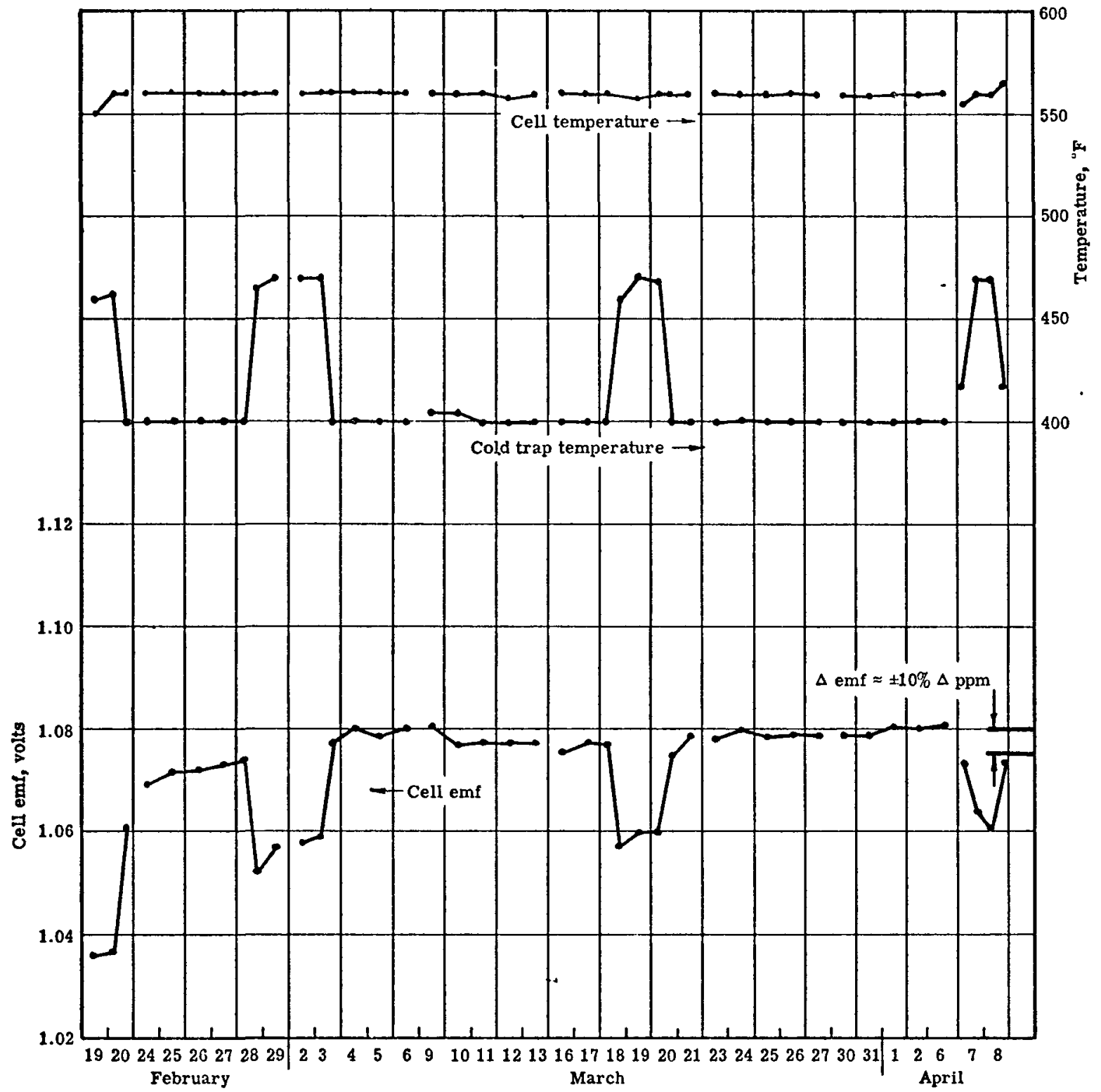

FIG. 3 - $\mathrm{ThO}_{2}-\mathrm{Y}_{2} \mathrm{O}_{3}$ CELL - LONG TIME STABILITY TEST 


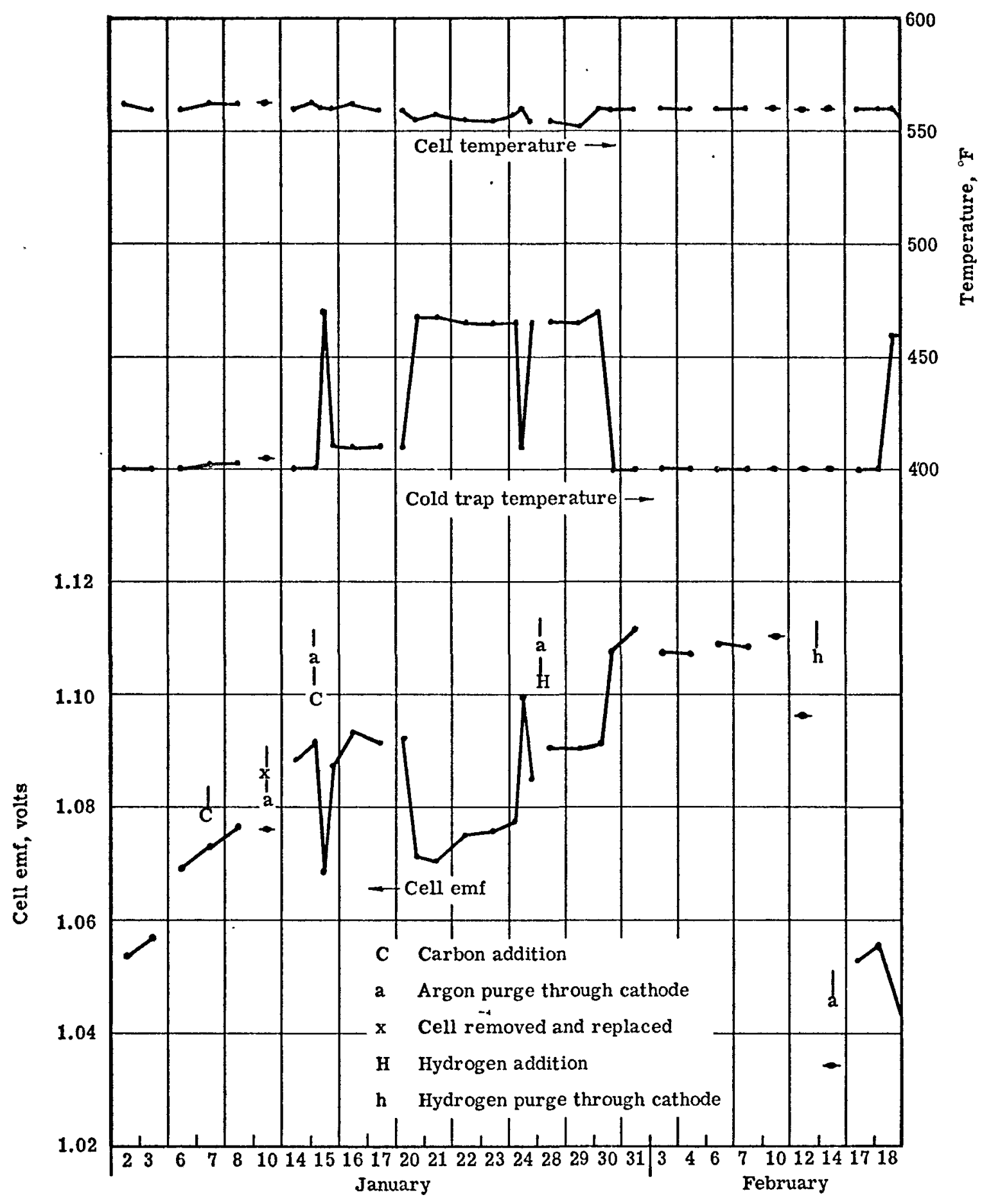

FIG. $4-\mathrm{ThO}_{2}-\mathrm{Y}_{2} \mathrm{O}_{3}$ CELL - INITIAL TESTS ON IMPURITY ADDITIONS, ETC. 
the effect was apparently temporary. The important point is that throughout all of these tests, and for over a month afterward, the meter . responded reproducibly and nearly theoretically to changes in cold trap temperature and showed excellent stability.

The tests described so far have utilized rather fragile laboratory models. Current work is directed to the design, development, and testing of more rugged prototype meters which will be suitable for testing in the field. The major problem in mechanical design of the sensor is the ceramic-to-metal seal which is required. Three of the methods for obtaining this seal are:

1. Rubber O-ring seal to the ceramic in the gas space above the sodium

2. Frozen sodium seal along the ceramic tube

3. Ceramic-to-metal braze.

A meter design using a frozen sodium seal is the preferred choice for immediate use. The gas space seal makes the ceramic tube too susceptible to breakage by thermal shock, which would result from slight fluctuations in the liquid level. The ceramic-to-metal brazed joint is highly desirable, but requires substantially more development and is, therefore, not available for immediate use. Work is continuing to develop the ceramic-to-metal braze joint.

A typical meter design using a frozen sodium primary seal is shown in Fig. 5 . 


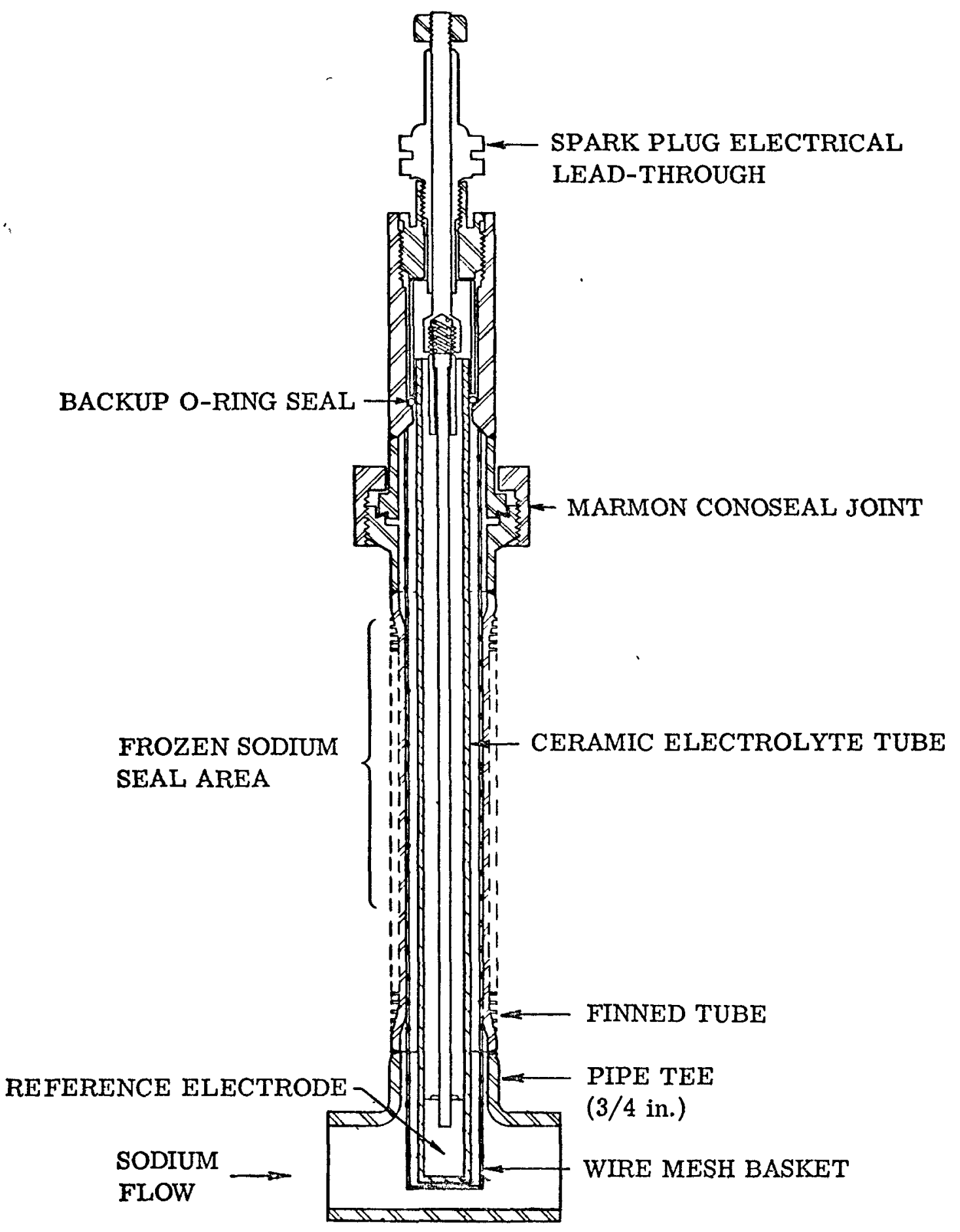

FIG. 5 - ELECTROCHEMICAL OXYGEN METER ASSEMBLY 
Important criteria for the mechanical design were:

1. Protecting the sodium system and personnel from leaks and other problems associated with breakage of the ceramic tube

2. Easy installation and replacement of the sensor element in the field

3. Compatibility of the mechanical design with any of electrolytereference electrode combinations being considered.

The sensor (electrolyte tube and reference electrode) is housed in a finned stainless steel tube which is welded into a $3 / 4-$ in. tee in the sodium piping. About $1 / 2$ in. length at the bottom end of the ceramic is exposed to turbulent sodium flow. Sodium is allowed to freeze in the annular space between the ceramic and finned tube. A rubber O-ring or other material positions the ceramic during installation, and acts as a low temperature backup seal. A stainless steel cap is attached, by means of a Marmon Conoseal, over the low-temperature open end of the sensor. This is to maintain an inert gas over the reference electrode, to permit easy replacement of the sensor element, and to contain sodium if the primary seal or the ceramic fails. A stainless steel wire mesh basket surrounds the ceramic tube. This catches any ceramic pieces in case the tube breaks. The basket is attached to the upper cap so that pieces can be retrieved when the cap is removed. A spark plug or Conax electrode gland in the cap provides an electrical lead-through to make contact with the reference electrode.

A schematic diagram of a meter installation is shown in Fig. 6. 


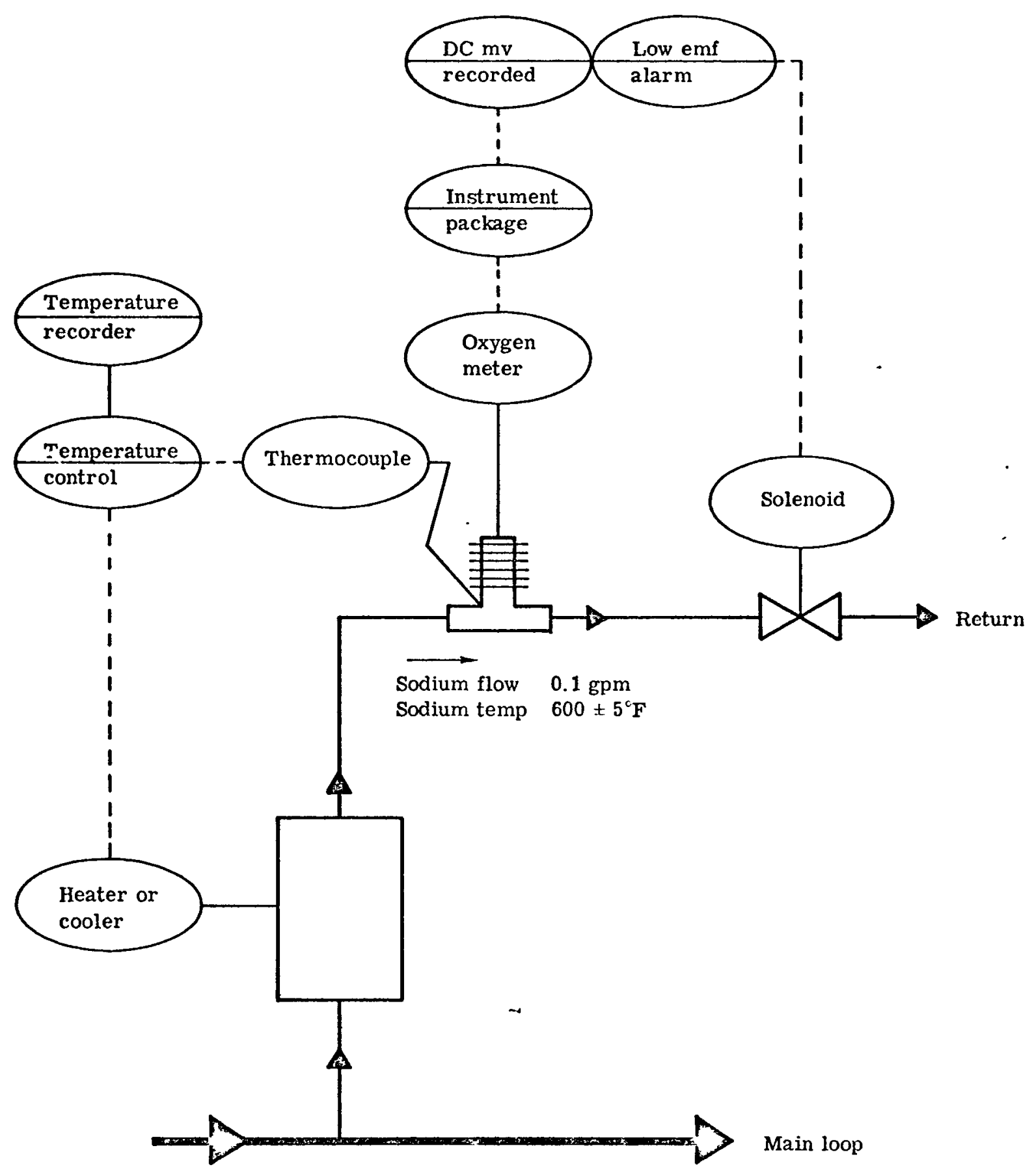

FIG. 6 - SCHEMATIC OF OXYGEN METER INSTALLATION 
It should be installed in a bypass or other line with a flow of about 0.1 gallons per minute or more. The meter is intended to operate at a minimum of 560 to a maximum of $600^{\circ} \mathrm{F}$. However, within this range the sensor temperature should be constant within $\pm 5^{\circ} \mathrm{F}$. The installation would require a means for controlling the temperature and flow of sodium past the sensor. In addition, a shutoff valve downstream of the meter would be desirable. The meter will provide an alarm signal which can close the downstream valve if the ceramic tube breaks.

Meters of essentially this design will be available for field testing in the near future. It is hoped that sufficient interest can be generated so that the meter can be tested in at least three field sites. This field testing and additional laboratory work should provide a basis for confidence and further improvements in the design and performance of the electrochemical oxygen meter.

\section{REFERENCES}

1. L. Vautrey, Test Rigs for the Rapsodie Coolant Circuits, Nuc. Eng., 8:3:1 (Sept. 1963).

2. H. Steinmetz, Development of a Continuous Meter for Oxygen in Sodium, Reports Issued:

UNC-5000 January 15, 1962

UNC-5010 April 15, 1962

UNC-5028 July 15, 1962

UNC-5032 August 24, 1.962

UNC-5050 January 25, 1963 